\title{
Exhaust Emissions from Engines Fuelled with Petrol, Diesel and their Blends with Biodiesel Produced from Waste Cooking Oil
}

\author{
Cynthia Ibeto*, Chinaecherem Ugwu \\ Department of Pure and Industrial Chemistry, University of Nigeria, Nsukka, Enugu State, Nigeria
}

Received: 31 March 2018

Accepted: 2 August 2018

\begin{abstract}
A study of exhaust emissions from engines in Enugu State, Nigeria fuelled with petrol, diesel and their blends with biodiesel was carried out. The biodiesel was produced from waste cooking oil via transesterification and both were analysed using ASTM methods. Exhaust emissions $\left(\mathrm{CO}, \mathrm{CO}_{2}, \mathrm{O}_{2}\right.$, NO and NOx) from petrol (motorcycles, tricycles, mini-buses and passenger cars) and diesel vehicles (tankers and trailers) as well as big and small capacity generators were analysed using a Bacharach portable combustion analyzer 2. Petrol and diesel were blended with biodiesel and used to fuel generators and vehicles at different blend ratios (B5 to B40). The diesel vehicles emitted much lower concentrations of $\mathrm{CO}$ and $\mathrm{CO}_{2}$ but higher NOx than the petrol vehicles. Small capacity generators emitted more $\mathrm{CO}$ while large capacity generators emitted more $\mathrm{NOx}$ and $\mathrm{CO}_{2}$. For all blends, there was a significant reduction in $\mathrm{CO}, \mathrm{CO}_{2}$ and $\mathrm{NOx}$ emitted in the small and large petrol-biodiesel generators. However in the diesel-biodiesel generator there was an increase in NOx emission and a decrease in $\mathrm{CO}$ and $\mathrm{CO}_{2}$. Also, CO from all the petrol vehicles exceeded the obsolete EU 2 limit. Therefore, these emissions could enhance health and environmental hazards associated with their pollution.
\end{abstract}

Keywords: biodiesel, diesel, air, exhaust emissions, waste cooking oil

\section{Introduction}

The last century has seen an increase in the global automobile population, making the transportation sector very crucial to a nation's economy. Developing countries account for about $10 \%$ of the global automobile population and a little over $20 \%$ of the global transport energy consumption [1]. The transportation sector consumes over $50 \%$ of the global oil demand,

*e-mail: cynthia.ibeto@unn.edu.ng resulting in about $25 \%$ of anthropogenic $\mathrm{CO}_{2}$ emissions. Within the sector, emissions from motor vehicles account for approximately $75 \%$ of direct $\mathrm{CO}_{2}$ emissions [2].

This vehicular growth has not been properly checked by approved environmental regulating bodies, leading to increased levels of pollution [3]. With the rapidly rising mobility that accompanies it, the increase in automobile emissions will be greater than in developed nations. Steady growth in vehicular populations has put environmental stress on urban centres in various forms, particularly causing poor air quality. There is growing evidence that links vehicle pollutants to human 
ill health. In a study by Wang et al., [4], decreased attention of urban children was significantly associated with traffic-related pollution. Also, motor vehicles are major emission sources for several air pollutants, including nitrogen oxides ( $\mathrm{NOx}$ ) and carbon monoxide (CO) [5]. These pollutants have significant health and ecological effects. For example, high content of atmospheric $\mathrm{CO}$ leads to asphyxiation, which affects the proper functioning of different organs, resulting in impaired concentration, slow reflexes and confusion $[6,7]$. Wheezing and coughing are common effects of nitrogen oxide toxicity. However, dyspnea, chest pain, nose, eyes or throat irritations, headache, bronchospasm, diaphoresis, fever and pulmonary edema may also occur [8].

Mobile source pollution is increased by disorganized road networks, inefficient vehicles, fuel adulteration and traffic congestion [9]. The extent of automobile pollution is also based on the attributes of vehicular congestion movement rate, repair status and life span [10]. Particularly, poor vehicle maintenance culture and importation of old vehicles, which culminates in an automobile fleet dominated by a class of vehicles known as "super emitters" with high emission of harmful pollutants, has raised this figure of emission concentration [11]. These situations are alarming and are predicated on the poor economic disposition of developing countries.

One of the largest contributors to air pollution in urban environments are actually motor vehicles [12]. Particularly, air pollution problems in Nigeria are mainly from automobile exhaust due to the numerous and common outdoor activities. The general population stays daily on very busy roads to do their work, sell their wares or wait for public transport. Also, in Enugu state, Nigeria, the absence of a reliable public transport system has worsened air pollution because of an increased number of old second-hand cars, taxis, motorbikes, substandard petrol and other products imported into the country. There is presently no available data on the emission and impact of air pollution in Enugu, but it is anticipated that air pollution will become a major health problem if adequate mitigation measures are not employed [13]. In Nigeria, a lot of attention is given to general industrial pollution, including oil industries, with little reference to pollution caused by air pollution from transportation sources [14]. Pollution from mobile transportation is on the rise due to increases in per capital vehicle ownership, thus resulting in high congestion on Nigeria city roads and increases in the concentration of pollutants in the air, and consequently increasing health risks for the human population. With a public ban placed on motorcycles in major cities in Nigeria, towns like Nsukka have too many motorcycle operators, and no proper investigation has been made into the estimation of the level of emissions from motorcycles in comparison with that from cars and tricycles. Nigeria is also at the brink of economic meltdown cum the persistent power shortage experienced, hence purchasing and operating of smallcapacity petrol generators (SCGG) seem the most viable option for most Nigerians, but the ban placed on the importation of this set of generators makes it a very difficult option. It is therefore necessary to analyse the gaseous emissions from these generators and see the difference between them and the large-capacity petrol generators (LCGG). It is also necessary to investigate ways of reducing the emissions from vehicles and generators - especially the publicly banned ones (e.g., motorcycles and SCGGs) by blending their fuels with biodiesel fuel.

Some studies have been carried out on exhaust emissions. Passenger cars were analysed for emissions on Nigerian roads. Results showed that the major types of tail pipe emission from the vehicles used in Nigeria are $\mathrm{CO}_{2}, \mathrm{NOx}, \mathrm{CO}$ and $\mathrm{O}_{2}$ [10]. The impact of vehicular emissions has also been studied in Benue and Akwa Ibom States in Nigeria by assessing the levels of gaseous emissions in the air. Results from Benue were slightly higher than Nigerian air quality standards $[15$, 16].

Compared with the large volume and varieties of studies carried out on air exhaust emissions in the developed world [17], studies for Nigeria are quite scarce. Therefore, this study was carried out to evaluate the level of pollution from automobile and generator exhaust gases $\left(\mathrm{CO}, \mathrm{CO}_{2}, \mathrm{O}_{2}\right.$ and $\left.\mathrm{NOx}\right)$ in Nsukka, Enugu State, Nigeria through monitoring of gaseous emissions from petrol and diesel, and analyzing the impact of biodiesel blends on exhaust emissions.

\section{Experimental}

The study was carried out at the National Centre for Energy Research and Development, University of Nigeria Nsukka. The waste cooking oil was obtained from a restaurant. Reagents used were analytical grade. Methanol and sodium hydroxide were products of Merck, Darmstadt, Germany (99.7\% purity) and Loba Chemie GmbH Switzerland (85\% purity). The oil was characterised for specific gravity using a specific gravity bottle; moisture content by oven (BTOV 1423) dry method; kinematic viscosity using a Ferranti portable viscometer model VL; the acid, peroxide, iodine and saponification values by titrimetry; refractive index using Abbe's refractometer; flash point using semi-automatic Clevaland flask point tester; pour point using cooling method; acid number using ASTM D 664; percentage free fatty acid (\% FFA) (as Oleic) was determined by the acid value with the factor 0.0503 . Thus $\%$ FFA $=0.503 \times$ acid value [18]. Sulphur content was determined by energy dispersive X-ray fluorescence spectroscopy, ash content by ASTM D874 and calorific value using a Hewlett adiabatic bomb calorimeter model 1242. 


\section{Biodiesel Production, Separation and Purification}

The transesterification reaction was carried out by measuring $1000 \mathrm{ml}$ of the sieved waste cooking oil with an excess amount of methanol $(220 \mathrm{ml}$ per liter of oil) into an airtight clean conical flask containing a magnetic stirrer and then heated to $55^{\circ} \mathrm{C}$. A catalyst $(1 \% \mathrm{NaOH})$ was added and made airtight immediately in order to improve the transesterification reaction. The reaction mixture was then shaken and maintained between 60 $65^{\circ} \mathrm{C}$ for 60 minutes [19]. At the end of the reaction, the product was allowed to settle overnight. Two distinct liquid phases: crude ester phase at the top and glycerol phase at the bottom were produced in a successful transesterification reaction.

The top ester phase (biodiesel) was separated from the bottom glycerol phase by transferring to a clean $1000 \mathrm{ml}$ conical flask. The biodiesel was then purified by washing several times with warm distilled water to a neutral $\mathrm{pH}$ to remove all the residual by-products such as excess alcohol, excess catalysts, soap, glycerine and other impurities. The volume of distilled water added was approximately $15 \%$ of the biodiesel volume. The flask was shaken gently for 1 minute and placed on a table to allow separation of biodiesel and water layers. After separation, the biodiesel was transferred to a clean conical flask [19]. The biodiesel was characterized using the same methods as the oil.

\section{Sample Size of Vehicles and Generators}

The vehicles and the generators were selected at random based on availability and corporation of the automobile and generator operators in Nsukka, Enugu State, Nigeria. The engines analysed were diesel vehicles (6 trailers and 6 tankers), petrol vehicles (10 each of motorcycles, tricycles, buses and passenger cars) and generators (10 small (2 kVA) capacity and 10 large (7.5 kVA) capacity). In addition, petrol and diesel were blended with biodiesel in ratios ranging from B10 $(10 \%$ biodiesel and $90 \%$ petrol/diesel) to B40 (40\% biodiesel and $60 \%$ petrol/diesel). Blended engines were a petrolbiodiesel small capacity generator, a petrol-biodiesel large capacity generator, a diesel-biodiesel large capacity generator and a petrol-biodiesel motorcycle.

\section{Equipment Setup and Exhaust Gas Measurement}

A gas analyser (Bacharach portable combustion analyser 2) was used for the study. The gas analyser was comprised of a 5-gas analyzer meter, an exhaust probe, sample conditioning probe and a printer. The meter is fitted with water trap, a filter and a protective rubber sleeve. The equipment measures the volume percentage of $\mathrm{CO}, \mathrm{CO}_{2}, \mathrm{O}_{2}, \mathrm{NO}$, and $\mathrm{NOx}$ in the exhaust gas. The $\mathrm{CO}_{2}$ and $\mathrm{O}_{2}$ emissions are measured in percentages whereas $\mathrm{CO}, \mathrm{NO}$ and $\mathrm{NOx}$ (added values of $\mathrm{NO}$ and $\mathrm{NO}_{2}$ ) are measured in ppm. At the start of each experiment, the gas analyser was first purged to ensure there was no air trapped that could affect the results. The filter was regularly checked to ensure that it was clean and not clogged with particles. The startup time before testing was about 70 seconds. When ready for use, the analyser probe was fitted to the exhaust pipe and firmly held. The vehicle operator was required to run the engine in idle mode for five minutes and then measurements were done. The typical time for testing one vehicle/generator was five minutes. In the case of motorcycles, the operators were required to ride the motorbike through a distance of $1 \mathrm{~km}$ and then measurement of the emissions was done [10]. To compare the EU standard in $\mathrm{g} / \mathrm{km}$ to the results obtained in ppm, the conversion employed (equations 1-3) was based on the assumptions of Alkama et al., [20] and conversions adopted by Pilusa et al., [21].

$$
\begin{gathered}
\mathrm{CO}(\mathrm{g} / \mathrm{km})=9.66 \times 10^{-3} \times \mathrm{CO}(\mathrm{ppm}) \\
\mathrm{NOx}(\mathrm{g} / \mathrm{km}) 28.56 \times 10^{-3} \times \mathrm{NOx}(\mathrm{ppm}) \\
\mathrm{CO}_{2}(\mathrm{~g} / \mathrm{km})=166.3 \times \mathrm{CO}_{2}(\mathrm{vol} \%)
\end{gathered}
$$

\section{Results and Discussion}

The waste cooking oil and the biodiesel produced were analysed for their fuel properties in order to determine their suitability for biodiesel production and engine fuel respectively. The results are shown in Table 1 . The specific gravity of the oil and biodiesel was 0.99 and 0.90 respectively. The gravity of the biodiesel

Table 1. Quality parameters of waste cooking oil and biodiesel.

\begin{tabular}{|c|c|c|}
\hline Parameters & $\begin{array}{c}\text { Waste } \\
\text { cooking oil }\end{array}$ & Biodiesel \\
\hline Specific gravity & 0.99 & 0.90 \\
\hline Moisture Content $(\%)$ & 0 & 0.05 \\
\hline Kinematic Viscosity $\left(\mathrm{m}^{2} / \mathrm{s}\right)$ & 7.52 & 1.90 \\
\hline Acid Value $(\mathrm{mgKOH} / \mathrm{g})$ & 1.64 & 0.22 \\
\hline Free Fatty Acid $(\%)$ & 0.82 & 0.11 \\
\hline Peroxide Value $(\mathrm{mgKOH} / \mathrm{g})$ & 4.98 & - \\
\hline Iodine Value $(\mathrm{gI} / \mathrm{l} / 00 \mathrm{~g})$ & 9.90 & 13.45 \\
\hline Refractive $\mathrm{Index}$ & 1.47 & - \\
\hline Saponification Value $(\mathrm{mgKOH} / \mathrm{g})$ & 257.93 & - \\
\hline Sulphur Content $(\%)$ & - & 0.01 \\
\hline Flash Point $\left({ }^{\circ} \mathrm{C}\right)$ & - & 155 \\
\hline Pour Point $\left({ }^{\circ} \mathrm{C}\right)$ & - & -3.00 \\
\hline Ash Content $(\%)$ & - & 0.09 \\
\hline Calorific Value $(\mathrm{KJ} / \mathrm{Kg})$ & - & 34,400 \\
\hline
\end{tabular}




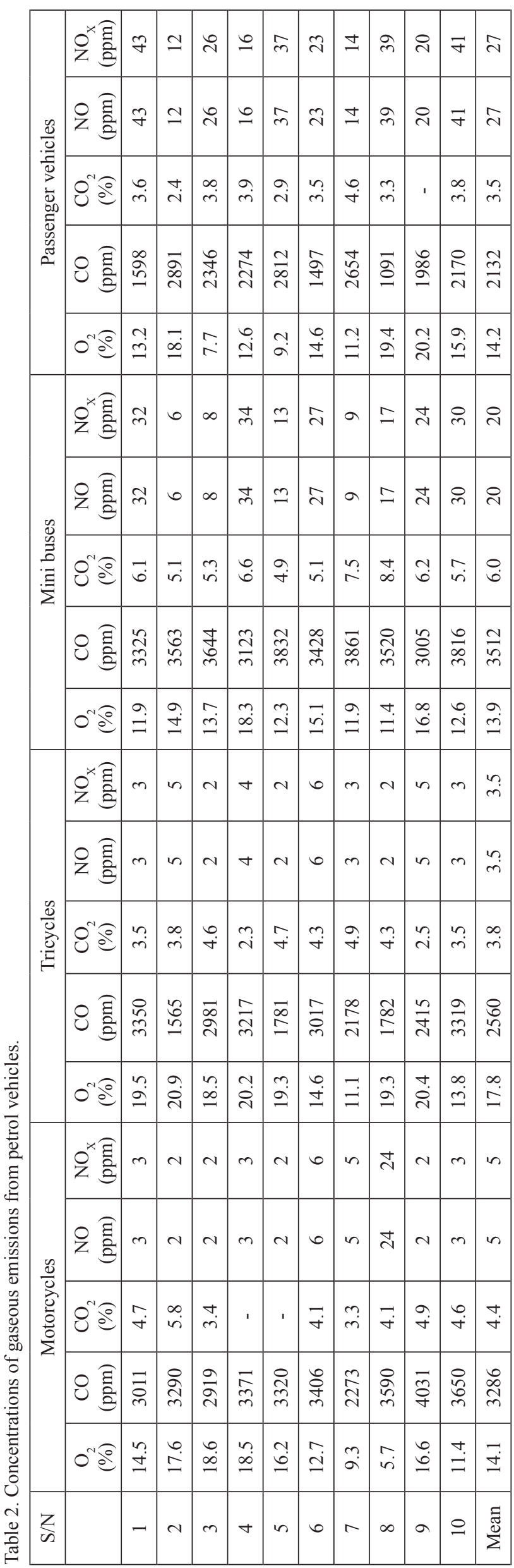

was within the EN 14214 standard range of (0.86-0.09) for biodiesel. This is important since fuel is delivered by the engine on a volumetric basis and biodiesel density is higher than that of diesel. Studies have shown that higher engine fuel consumption for biodiesel is partly due to its high density. Also, higher content of biodiesel in the blends results in higher emissions of particulate matter [22]. The moisture content of the waste cooking oil was $0 \%$, which favours transesterification. Moisture in vegetable oils is a great impediment to the formation of esters due to increased tendency of soap formation and thus will have to be minimal for transesterification to occur [23]. The moisture content $(0.05 \%)$ of the biodiesel produced was within the acceptable limit of $0.05 \%$ for ASTM D6751. The amount of water in biodiesel determines the calorific value and, above all, the shelf life of the fuel. Biodiesel with high water content has clearly lower oxidation stability, which favours oxidation products to be formed during long storage periods. These can cause engine problems due to deposits, particularly with the injection system. The calorific value of the obtained biodiesel was $34400 \mathrm{KJ} / \mathrm{kg}(34.4 \mathrm{MJ} / \mathrm{kg})$, which is only slightly higher than that of EN14214 standard $(32.9 \mathrm{MJ} / \mathrm{Kg})$ for biodiesel.

Kinematic viscosity is a measure of fluid resistance to flow. This is one of the advantages of the use of biodiesel as an alternative fuel instead of neat vegetable oils and animal fats that cause operational problems such as engine deposits when used directly as fuels. The kinematic viscosity of the oil $\left(7.52 \mathrm{~m}^{2} / \mathrm{s}\right)$ was within the recommended standard range of 6.3 to $8.8 \mathrm{~m}^{2} / \mathrm{s}$, while that of the biodiesel $\left(1.9 \mathrm{~m}^{2} / \mathrm{s}\right)$ measured at $40^{\circ} \mathrm{C}$ was in conformity with the ASTM D6751 standard range of 1.9-6.0. This also shows that the transesterification method employed effectively reduced the kinematic viscosity as required.

The acid value of the waste cooking oil and biodiesel were $1.64 \mathrm{mgKOH} / \mathrm{g}$ and $0.22 \mathrm{mgKOH} / \mathrm{g}$, respectively, which was within the recommended standard of $0.50 \mathrm{mgKOH} / \mathrm{g}$ and $0.8 \mathrm{mgKOH} / \mathrm{g}$ for EN 14214 and ASTM D6751 respectively. High acid value leads to catalyst deactivation. Acid value is also a direct measure of the content and the level of free fatty acids, which has an influence on fuel aging. The presence of high free fatty acids can lead to corrosion during storage or transportation and may be a consequence of water in the fuel. The peroxide value of the waste cooking oil at 4.98 $\mathrm{mgKOH} / \mathrm{g}$ was very low compared to the standard of $10 \mathrm{mEq} / \mathrm{kg}$ by FAO/WHO [24] for fresh edible oil. This was attributed to low levels of oxidative rancidity of the oils, high levels of antioxidants like propyl gallate, and susceptibility of oil to deterioration when used as a feedstock for biodiesel. Iodine value is an important characteristic that determines the degree of unsaturation of fats and oils [25]. Therefore, high iodine value indicates high unsaturation of fats and oil.

The iodine value of the oil and biodiesel used in this study were $9.9 \mathrm{gI}_{2} / 100 \mathrm{~g}$ and $13.45 \mathrm{gI}_{2} / 100 \mathrm{~g}$, respectively, 
Table 3. Concentrations of gaseous emissions from diesel vehicles.

\begin{tabular}{|c|c|c|c|c|c|c|c|c|c|c|}
\hline $\mathrm{S} / \mathrm{N}$ & \multicolumn{5}{|c}{ Tankers } & \multicolumn{5}{c|}{ Trailers } \\
\hline & $\mathrm{O}_{2}(\%)$ & $\begin{array}{c}\mathrm{CO} \\
(\mathrm{ppm})\end{array}$ & $\begin{array}{c}\mathrm{CO}_{2} \\
(\%)\end{array}$ & $\begin{array}{c}\mathrm{NO} \\
(\mathrm{ppm})\end{array}$ & $\begin{array}{c}\mathrm{NO}_{\mathrm{x}} \\
(\mathrm{ppm})\end{array}$ & $\mathrm{O}_{2}(\%)$ & $\begin{array}{c}\mathrm{CO} \\
(\mathrm{ppm})\end{array}$ & $\begin{array}{c}\mathrm{CO}_{2} \\
(\%)\end{array}$ & $\begin{array}{c}\mathrm{NO}^{2} \\
(\mathrm{ppm})\end{array}$ & $\begin{array}{c}\mathrm{NO}_{\mathrm{x}} \\
(\mathrm{ppm})\end{array}$ \\
\hline 1 & 16.0 & 597 & 1.5 & 50 & 126 & 16. & 928 & 1.9 & 38 & 102 \\
\hline 2 & 12.8 & 705 & 1.2 & 17 & 103 & 16.3 & 971 & 1.1 & 55 & 109 \\
\hline 3 & 13.7 & 728 & 1.9 & 37 & 113 & 16.6 & 729 & 2.3 & 46 & 104 \\
\hline 4 & 15.6 & 840 & 1.5 & 41 & 106 & 16.7 & 890 & 1.4 & 33 & 89 \\
\hline 5 & 16.1 & 671 & 1.6 & 53 & 132 & 17.2 & 551 & 0 & 49 & 100 \\
\hline 6 & 16.2 & 831 & 1.7 & 28 & 108 & 18.7 & 583 & 0 & 50 & 95 \\
\hline Mean & 15.1 & 729 & 1.6 & 74 & 115 & 17 & 745 & 1.1 & 55 & 100 \\
\hline
\end{tabular}

which was comparably lower than $120 \mathrm{gI}_{2} / 100 \mathrm{~g}$ EN14214 standard. The biodiesel had a flash point of $155^{\circ} \mathrm{C}$ and was within the recommended range of $>130^{\circ} \mathrm{C}$ and $>101^{\circ} \mathrm{C}$ of ASTM D6751 and EN 14214 respectively. This indicates that the biodiesel is not highly inflammable and therefore poses no risk of fire outbreak - especially in case of accidents. It was also characterized by low sulphur content $(0.01 \%)$, which is considered to be an advantage since the presence of sulphur in the fuel leads to the formation of acidic sulphur oxides $\left(\mathrm{SO}_{2}\right.$ and $\left.\mathrm{SO}_{3}\right)$, which are corrosive gases that will corrode the engine parts and also lead to environmental pollution.

The analysis of gaseous emissions from vehicles and generators showed that $\mathrm{O}_{2}, \mathrm{CO}_{2}, \mathrm{NOx}$, and $\mathrm{CO}$ were emitted during combustion of the fossil fuels. Table 2 shows the results of the analysed gaseous emissions from petrol vehicles. The mean results of $\mathrm{CO}_{2}$ and $\mathrm{CO}$ emitted by minibuses were higher than those emitted by other petrol vehicles. Passenger cars emitted highest mean NOx value (27.1 ppm) while minibuses, motorcycles and tricycles emitted $20 \mathrm{ppm}, 5.2 \mathrm{ppm}$ and $3.5 \mathrm{ppm}$ respectively. In comparison with the second European emission (EU 2) standard [26] adopted by Nigeria [27], as against the EU 6 standard [26] being used in Europe, motorcycles (3286.10 ppm) emitted four times the CO limit of $569.36 \mathrm{ppm}$ for two-wheelers, and hence produced an excess of $2716.6 \mathrm{ppm} \mathrm{CO}$, which could be detrimental to the environment. However, the NOx concentration of motorcycles $(5.2 \mathrm{ppm})$ was below the standard value (10.50 ppm) for NOx. Tricycle CO (2560.5 ppm) emissions were $1835.64 \mathrm{ppm}$ above the permissible limit of 724.64 ppm for three-wheelers but emitted an NOx value (3.5 ppm) below the permissible limit of $14.01 \mathrm{ppm}$. The $\mathrm{CO}$ of passenger car (2131.9 ppm) and minibus (3511.7 ppm) emissions was above the permissible limit of $227.74 \mathrm{ppm}$. There is no standard limit for the emissions of $\mathrm{NOx}$ and $\mathrm{CO}_{2}$ in the EU 2 emission standard for light-duty petrol vehicles, but the emitted NOx value exceeded the EU 6 permissible limit of $2.10 \mathrm{ppm}$. Although Nigeria is using the EU 2 Standard, comparison with EU 6 is important since there is a direct correlation between concentrations of pollutants from vehicular emissions and the general health of the population. This is even more important for densely populated countries, e.g., Nigeria.

For diesel vehicles (Table 3), the mean $\mathrm{CO}$ and NOx emitted from tankers were below the EU 2 emission standard permissible limit of 1113.89 ppm and $1054.86 \mathrm{ppm}$, respectively, for heavy-duty diesel vehicles. But on comparison with the EU 6 emission standard, tankers emitted more $\mathrm{CO}$ and NOx above the permissible limit of $54.39 \mathrm{ppm}$ (CO) and $60.27 \mathrm{ppm}$ (NOx). Trailers on the other hand emitted $369.09 \mathrm{ppm}$ less $\mathrm{CO}$ against the permissible limit of $1113.89 \mathrm{ppm}$ and $955.03 \mathrm{ppm}$ less NOx against the permissible limit of $1054.86 \mathrm{ppm}$ for EU 2 standard. On comparison with the current EU 6 emission standard, trailers emitted $37.69 \mathrm{ppm}$ more $\mathrm{CO}$ above the permissible limit of $417.11 \mathrm{ppm}$ and $39.56 \mathrm{ppm}$ more NOx above the permissible limit of $54.39 \mathrm{ppm}$. Gaseous emissions (CO and NOx) from trailers and tankers appear to be environmentally friendly according to the Nigeria standard, but when compared to the current EU 6 standard, they exceeded the maximum permissible limit.

Each of the petrol vehicles emitted more than twice the $\mathrm{CO}_{2}$ of the diesel vehicles. Among the six vehicles considered, minibuses and tricycles emitted the highest (27\%) and lowest $\mathrm{CO}_{2}(17 \%)$ respectively, while motorcycles and passenger cars accounted for $21.5 \%$ and $19 \%$ respectively of the total $\mathrm{CO}_{2} \cdot \mathrm{CO}_{2}$ is formed when the fuel is completely burnt. Diesel is a long-chain heavier (hexanes) compound than petrol, which means that it has a higher number of carbon atoms, resulting in greater $\mathrm{CO}_{2}$ emissions, yet diesel vehicles emit less $\mathrm{CO}_{2}$ than petrol engines. This could be attributed to the fact that diesel engines have more fuel efficiency than petrol engines and hence burn less carbon per kilometre [28]. Petrol vehicles emitted about three times more CO than diesel vehicles which shows that petrol vehicles had more incomplete combustion than diesel vehicles. This is due to insufficient air present to completely burn the fuel. $\mathrm{CO}$ emission is common in petrol engines since it always operates close to stoichiometric conditions, while diesel engines are lean-burn engines, hence the chances 
Table 4. Concentrations of gaseous emissions from petrol generators.

\begin{tabular}{|c|c|c|c|c|c|c|c|c|c|c|}
\hline S/N & \multicolumn{4}{|c|}{ Small Capacitor Petrol Generators } & \multicolumn{5}{c|}{ Large Capacitor Petrol Generators } \\
\hline & $\mathrm{O}_{2}(\%)$ & $\begin{array}{c}\mathrm{CO} \\
(\mathrm{ppm})\end{array}$ & $\begin{array}{c}\mathrm{CO}_{2} \\
(\%)\end{array}$ & $\begin{array}{c}\mathrm{NO} \\
(\mathrm{ppm})\end{array}$ & $\begin{array}{c}\mathrm{NO}_{\mathrm{x}} \\
(\mathrm{ppm})\end{array}$ & $\mathrm{O}_{2}(\%)$ & $\begin{array}{c}\mathrm{CO} \\
(\mathrm{ppm})\end{array}$ & $\begin{array}{c}\mathrm{CO}_{2} \\
(\%)\end{array}$ & $\begin{array}{c}\mathrm{NO}^{2} \\
(\mathrm{ppm})\end{array}$ & $\begin{array}{c}\mathrm{NO}_{\mathrm{x}} \\
(\mathrm{ppm})\end{array}$ \\
\hline 1 & 18.5 & 2847 & 2.1 & 29 & 29 & 15.7 & 2868 & 5.4 & 33 & 33 \\
\hline 2 & 14.2 & 3891 & 4.8 & 26 & 26 & 5.9 & 4021 & 10.8 & 26 & 26 \\
\hline 3 & 7.5 & 2311 & 7.6 & 19 & 19 & 7.3 & 3029 & 8.8 & 41 & 41 \\
\hline 4 & 9.1 & 3248 & 5.6 & 33 & 33 & 16.0 & 3865 & 3.2 & 25 & 25 \\
\hline 5 & 14.6 & 2130 & 6.4 & 23 & 23 & 12.2 & 1548 & 5.0 & 18 & 18 \\
\hline 6 & 18.0 & 1935 & 1.9 & 37 & 37 & 9.2 & 1955 & 7.2 & 45 & 45 \\
\hline 7 & 17.4 & 3271 & 4.5 & 16 & 16 & 13.2 & 3124 & 6.3 & 37 & 37 \\
\hline 8 & 12.0 & 3619 & 5.1 & 41 & 41 & 14.6 & 2138 & 5.5 & 19 & 19 \\
\hline 9 & 13.2 & 2477 & 6.2 & 20 & 20 & 11.0 & 3081 & 6.7 & 39 & 39 \\
\hline 10 & 16.8 & 3039 & 2.4 & 32 & 32 & 8.9 & 2847 & 6.9 & 20 & 20 \\
\hline Mean & 14.1 & 2877 & 4.7 & 27.6 & 27.6 & 11.4 & 2847 & 6.6 & 30 & 30 \\
\hline
\end{tabular}

of $\mathrm{CO}$ emission from diesel engine is less compared to that of petrol engines [29]. The highest NOx emissions were observed in diesel engines (trailers and tankers). The NOx emitted by tankers (114.7 ppm) were twice the sum of all the NOx emitted by the petrol vehicles, while that of trailers $(99.8 \mathrm{ppm})$, although lower than that of tankers (114.7 ppm), is actually higher than the sum of all the NOx emitted by petrol vehicles. Since NOx is formed when nitrogen reacts with oxygen at elevated temperatures, high cylinder temperatures lead to NOx formation as both nitrogen and oxygen in the incoming charge are usually inert at low temperature. As diesel engines operate at much higher cylinder pressure, which leads to high in-cylinder temperature, more nitrogen reacts with oxygen, hence NOx formation is dominant in diesel engines. This was also the case in other studies. For instance, Yasar et al., [28] reported that a diesel car emitted $0.1 \% \mathrm{CO}$ and $41 \mathrm{ppm}$ NOx while a petrol-used car emitted $1.8 \% \mathrm{CO}$ and 13 ppm NOx.

Table 4 shows the results of the emissions from both SCPGs and LCPGs. SCPGs emitted less mean $\mathrm{CO}_{2}(4.66 \%)$ than LCPGs $(6.58 \%)$, but slightly higher $\mathrm{CO}$. With the amount of $\mathrm{CO}_{2}$ and $\mathrm{CO}$ emitted by both the SCPG and LCPG, it is clear that the LCPG is more efficient in ensuring complete combustion. There was no $\mathrm{NO}_{2}$ detected in the two categories of generators measured as the volume of NOx equalled the volume of NO emitted. The LCPG emitted higher NOx than the SCPG; with its mean NOx emission value of $30.3 \mathrm{ppm}$ while SCPG was $27.6 \mathrm{ppm}$. Consequently SCPGs are responsible for $47.8 \%$ of the total NOx emitted by the petrol generators, while LCPG is responsible for about $52.2 \%$ of the total NOx emissions by petrol generators. LCGGs also emitted more $\mathrm{CO}_{2}$, which is not harmful to humans and is less harmful to the environment. SCGGs emitted more $\mathrm{CO}$, which is very harmful to both human health and the environment.
Generally, both generators and vehicles contribute significantly to air pollution. With an epileptic power supply and transportation needs as a result of increasing population, the numbers of vehicles and generators can only be on the increase. Comparing the results from generators and vehicles, it is seen that each contributes significantly to the pollution problems in the environment. Tankers emitted more NOx than every other vehicle and generator used, followed by trailers, but these two had the least $\mathrm{CO}$ and $\mathrm{CO}_{2}$ emissions. Inasmuch as diesel engines emit one-third the $\mathrm{CO}$ and $\mathrm{CO}_{2}$ that petrol engines emit, they on the other hand emit about thrice the NOx that the petrol engines emit. Tankers and trailers accounted for about $65 \%$ of the total NOx emissions while minibuses, passenger cars, tricycles, motorcycles, small capacity petrol generators and large capacity petrol generators all accounted for only about $35 \%$ of total NOx emissions. Minibuses emitted most $\mathrm{CO}$, while large capacity petrol generators emitted the highest $\mathrm{CO}_{2}$. Tricycles had an average $\mathrm{CO}$ and $\mathrm{CO}_{2}$ emissions and the least NOx emissions. While motorcycles had very low NOx emissions, they had very high CO emissions. SCGG, LCGG and small vehicles had very high NOx emissions compared to only the rest of petrol engines.

The excess $\mathrm{CO}, \mathrm{NOx}$ and $\mathrm{CO}_{2}$ emitted will directly increase the concentration of these gases in the air and hence affect air quality of the environment, which also affects human health and the environment. The severity of health effects from $\mathrm{CO}$ exposure depends on some factors, such as general health status and age of a person, duration of $\mathrm{CO}$ exposure, atmospheric concentration of $\mathrm{CO}$, etc. [30]. Also, ischemia apoptosis and hypoxia are known mechanisms of underlying CO toxicity [31]. Safe $\mathrm{CO}$ exposure can be characterized as exposure to an air concentration of CO that is less than the U.S. EPA's [32] National Ambient (outdoor) Air Quality Standards of 
9 ppm (8-hr average) or 35 ppm (1-hr average). NOx also is very harmful when inhaled beyond the permissible limit. $\mathrm{NO}_{2}$ concentration below $0.12 \mathrm{ppm}$ does not have any effect on humans. However, if exposed to high concentrations it will cause adverse health effects such as lung disease and influenza [33].

Petrol and biodiesel blended at two different ratios as shown in Table 5 were used to fuel small- and largecapacity petrol generators as well as a motorcycle. At B0, the small generators emitted $3.7 \% \mathrm{CO}_{2}$. At B5 there was no significant reduction in the $\mathrm{CO}_{2}$ emitted as $3.7 \%$ was still recorded. However, at B10, 2.70\% $\mathrm{CO}_{2}$ reduction was recorded. For carbon monoxide emissions, at $\mathrm{B} 0$ a $\mathrm{CO}$ value of $2847 \mathrm{ppm}$ was recorded, at $\mathrm{B} 5$ there was a $1.58 \%$ reduction in $\mathrm{CO}$ emitted. At B10, there was further reduction in the $\mathrm{CO}$ as 2730 ppm was recorded, which indicates a 4.12\% reduction in $\mathrm{CO}$ emitted. In the case of $\mathrm{NOx}$, there was also a large reduction of emissions for each blending ratio. At B0, $29 \mathrm{ppm}$ of $\mathrm{NOx}$ was emitted. At B5, about $17.24 \%$ reduction was observed and at $\mathrm{B} 10$, there was still a further reduction in emissions of $44.83 \%$ reduction with only $16 \mathrm{ppm}$ of $\mathrm{NOx}$. While for large generators, $\mathrm{CO}_{2}$ reductions were observed at every blend ratio although the concentrations emitted were higher than small generators and this was also the case for $\mathrm{CO}$ and NOx.

For the motorcycle, at $\mathrm{B} 0$, there was $10 \%$ reduction in emission of $\mathrm{CO}_{2}$ from $\mathrm{B} 0$ to $\mathrm{B} 10$. However, reduction in the volume of $\mathrm{CO}$ emitted occurred at each blend ratio, which exceeded the percentage $\mathrm{CO}_{2}$ reduction. $\mathrm{NOx}$ was emitted at each blend ratio, but unlike petrol generators, there was an increase in the volume of NOx emitted. At B10, the volume of NOx emitted was $10 \mathrm{ppm}$. This was the highest recorded volume of NOx. At $\mathrm{B} 5$, there was $80 \%$ reduction in the NOx volume recorded while a further $10 \%$ reduction occurred at $\mathrm{B} 0$, which confirmed that NOx emissions decreased with a decrease in the blending ratio. Therefore, for motorcycles the volume of $\mathrm{CO}_{2}$ and $\mathrm{CO}$ decreased with increases in the blend ratio, while NOx increased. Blending petrol with little biodiesel reduced emissions of $\mathrm{CO}, \mathrm{CO}_{2}$ and $\mathrm{NOx}$ for petrol generators. Similar trends were found in literature, where $\mathrm{CO}$ reduction is linear with biodiesel concentration in the fuel [34]. Therefore, blending petrol with biodiesel is most appropriate for petrol generators.

Blends of diesel and biodiesel were also studied (Table 6). At every blend ratio, there was a significant change in the volume of emissions. For B0, the diesel generator emitted $1.5 \% \mathrm{CO}_{2}$. At $\mathrm{B} 10$, there was $13.33 \%$ reduction and at $\mathrm{B} 20$ there was $33.33 \%$ reduction. However, at $\mathrm{B} 30$ and $\mathrm{B} 40$ there was no detectable $\mathrm{CO}_{2}$ emission. For CO, 1009 ppm was emitted at B0 with a reduction in emissions for all blending ratios, which was up to $37.46 \%$ at $\mathrm{B} 40$. Unlike petrol engines, $\mathrm{NO}_{2}$ was detected at every blend ratio as NOx equals the sum of the values of $\mathrm{NO}$ and $\mathrm{NO}_{2}$. The highest $\mathrm{NOx}$ value $(88 \mathrm{ppm})$ was recorded at $\mathrm{B} 40$ with a reduction for decreasing biodiesel ratio, which was $12.50 \%$ for

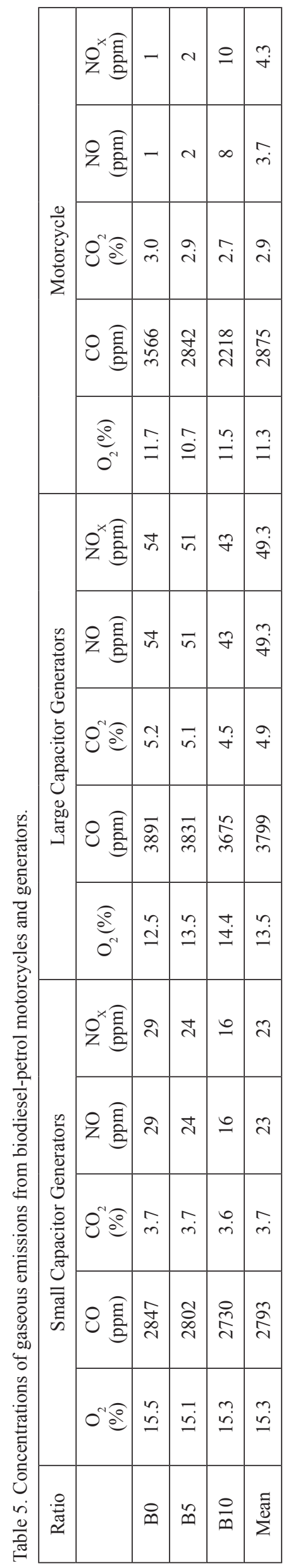


Table 6. Concentrations of gaseous emissions from biodieseldiesel large-capacitor generator.

\begin{tabular}{|c|c|c|c|c|c|}
\hline \multirow{2}{*}{ Ratio } & \multicolumn{5}{|c|}{ Concentrations } \\
\cline { 2 - 6 } & $\mathrm{O}_{2}(\%)$ & $\begin{array}{c}\mathrm{CO} \\
(\mathrm{ppm})\end{array}$ & $\begin{array}{c}\mathrm{CO}_{2} \\
(\%)\end{array}$ & $\begin{array}{c}\mathrm{NO} \\
(\mathrm{ppm})\end{array}$ & $\begin{array}{c}\mathrm{NO}_{\mathrm{x}} \\
(\mathrm{ppm})\end{array}$ \\
\hline B0 & 11.4 & 1009 & 1.5 & 43 & 77 \\
\hline B10 & 14.7 & 900 & 1.3 & 51 & 80 \\
\hline B20 & 16.2 & 820 & 1.0 & 53 & 82 \\
\hline B30 & 15.2 & 713 & -- & 57 & 83 \\
\hline B40 & 16.2 & 631 & -- & 62 & 88 \\
\hline Mean & 14.7 & 814 & 1.3 & 53 & 82 \\
\hline
\end{tabular}

B0. As the emission of NOx increased with increasing biodiesel ratio, it is also observed that the volume of $\mathrm{NO}_{2}$ emitted decreased with increases in biodiesel. The reasons for $\mathrm{CO}$ reduction in biodiesel generators and motorcycles could be attributed to the additional oxygen content in the fuel that enhances a complete combustion of the fuel. Abdullah et al. [35] also observed that NOx emissions increased while the carbon monoxide (CO) emissions decreased for the studied biodiesel blends. The increase in NOx emissions from diesel generators and the motorcycle could be attributed to the higher oxygen availability in the combustion chamber when using biodiesel, which could promote NO formation while NOx reduction in petrol generators could be due to engine construction and flame profile.

\section{Conclusions}

This study shows that exhaust gas pollution in Nigeria is high and will continue to increase if left unabated. Diesel vehicles emitted more NOx than the petrol vehicles, while petrol engines emit more $\mathrm{CO}_{2}$ and $\mathrm{CO}$ than the diesel engines. Large-capacity generators emitted lesser quantity of the harmful CO than smallcapacity generators. The emissions from both smalland large-capacity generators are within the range of vehicular emissions, but they exceeded the outdated EU 2 standard adopted by Nigeria. This implies that persons exposed to these emissions on a daily basis are likely to develop health complications over time.

Also, waste cooking oil, which is readily available, is a good feedstock for biodiesel production. Blending petrol or diesel with biodiesel produced from waste cooking oil reduced exhaust emissions. Biodieseldiesel blend reduced $\mathrm{CO}_{2}$ and $\mathrm{CO}$ emissions in diesel generators, but there was an increase in NOx emissions. On the other hand, biodiesel-petrol blend reduced emissions of $\mathrm{CO}, \mathrm{CO}_{2}$ and $\mathrm{NOx}$ in petrol generators, but an increase in emissions of only NOx in petrol motorcycles occurred. Therefore, bodiesel-petrol blend is ideal for reducing exhaust emissions from both smalland large-capacity petrol generators.

\section{Acknowledgements}

The authors are grateful to the National Centre for Energy Research and Development (NCERD), University of Nigeria, Nsukka for the use of their gas analyser. Also, technical assistance by the laboratory staff of NCERD is acknowledged.

\section{Conflict of Interest}

The authors declare no conflict of interest.

\section{References}

1. SHIVA M. Impact of transport policies on energy use and emissions. Municipal Engineer, 159 (4), 219, 2006.

2. KODJAK D. Policies to reduce fuel consumption, air pollution, and carbon emissions from vehicles in G20 nations. Washington, D.C.: International Council on Clean Transportation. Retrieved from http://www.theicct. org/policies-reduce-fuel-consumption-air-pollutionandcarbon-emissions-vehicles-g20-nations, 2015.

3. HAN X., NAEHER L.P. A review of traffic-related air pollution exposure assessment studies in the developing world. Environmental International 32, 106, 2006.

4. WANG J.M., JEONG C.H., ZIMMERMAN N., HEALY R.M., WANG D.K., KE F., EVANS G.J. Plume-based analysis of vehicle fleet air pollutant emissions and the contribution from high emitters Atmos. Meas. Tech. 8, 3263, 2015.

5. SURESH P., SHARAD G., ALOKE K.G. Evaluating effects of traffic and vehicle characteristics on vehicular emissions near traffic intersections. Transportation Research Part D, 180, 2009.

6. WALSH M.P. Mobile source related air pollution: effects on health and the environment. Encyclopedia of Environ Health 3, 803, 2011.

7. REŞITOĞLU İ.A., ALTINIŞIK K., KESKIN A. The pollutant emissions from diesel-engine vehicles and exhaust after treatment systems. A. Clean Techn Environ Policy 17, 15, 2015.

8. AZAM A., RIAHI-ZANJANI B. AND BALALI-MOOD M. Effects of air pollution on human health and practical measures for prevention in Iran. J Res Med Sci. 21, 65, 2016.

9. ASSAMOI E.M., LIOUSSE C. A new inventory for twowheel vehicle emissions in West Africa for 2002. Atmos. Environ. 44, 3985, 2010.

10. NASIR A., SHIRU P.B., MOHAMMED A. Analysis of Exhaust Gas Emissions from Gasoline engine-powered passenger vehicles in Nigeria. International Journal of Engineering Trends and Technology 34 (8), ISSN: 22315381. 405, 2016.

11. IBRAHIM B.G. Strategic Approach to Reducing Vehicle Emissions in Nigeria: Role of Fleet Operators", A lecture presented at safety managers training program, FRSC Academy, Nigeria, 2009.

12. FRANCO V., KOUSOULIDOU M., MUNTEAN M., NTZIACHRISTOS L., HAUSBERGER S., DILARA P. Road vehicle emission factors development: A review, Atmos. Environ. 70, 84, 2013. 
13. NWADIOGBU J.O., EZE K.A., EZIDINMA T.A., ECHEGI U.S.C. Contributions of vehicular traffic to carbon monoxide emissions in Enugu Metropolis. Nigeria. Scholars Research Library Archives of Applied Science Research. 5 (6), 189, 2013.

14. ATUBI A.O. Transport and the Environment: Towards Reducing Road Traffic Emissions in Nigeria. 9 (1), 58, 2015.

15. AMEH J., TOR-ANYIIN T., ENEJI I. Assessment of Some Gaseous Emissions in Traffic Areas in Makurdi Metropolis, Benue State, Nigeria. Open Journal of Air Pollution, 4, 175, 2015.

16. IHOM A.P., AGWU O.E., JOHN J.A. The Impact of Vehicular Emissions on Air Quality in Uyo, Nigeria. Mechanics, Materials Science \& Engineering 6, 178, doi: 10.13140/RG.2.1.1813.7845. 2016.

17. WANG J.M., JEONG C.H., ZIMMERMAN N., HEALY R.M., WANG D.K., KE F., EVANS G.J. Plume-based analysis of vehicle fleet air pollutant emissions and the contribution from high emitters Atmos. Meas. Tech. 8, 3263, 2015.

18. POMERANZ Y. Food Analysis: Theory and Practice. Springer Science \& Business Media, ISBN, 1461569982, 9781461569985. 716, 2013.

19. SAMUEL O.D., WAHEED M.A., BOLAJI B.O., DARIO O.U. Production of biodiesel from Nigerian restaurant waste cooking oil using blender. International Journal of Renewable Energy Research. 3 (4), 111, 2013.

20. ALKAMA R., AIT-IDIR F., SLIMANI Z. Estimation and Measurement of the Automobile. Global Nest J. 8, 227, 2006.

21. PILUSA T.J., MOLLAGEE M.M., MUZENDA E. Reduction of Vehicle Exhaust Emissions from Diesel Engines Using the Whale Concept Filter. Aerosol and Air Quality Research 12, 994, 2012.

22. XUE J., GRIFT T.E., HANSEN A.C. Effect of biodiesel on engine performances and emissions. Renewable and Sustainable Energy Reviews 15, 1098, 2011.

23. ABDULKAREEM A.S., UTHMAN H., AFOLABI A.S., AWONEBE O.L. Extraction and optimization of oil from moringa oleifera seed as an alternative feedstock for the production of biodeisel. Sustainable growth and application in renewable energy sources 243, 2011.

24. FAO/WHO Standard for edible fats and oils not covered by individual Standards. CODEX STAN 19-1981. Formerly CAC/RS 19-1969. Adopted in 1981. Revised in 1987, 1999. Amended in 2009, 2013, 2015, 2017. http://www.fao.org/ fao-who-codexalimentarius/codex-texts/list-standards/en/. 2017.
25. SADOUDI R., ALI AHMED D. Studies on physicochemical characteristics and fatty acid composition of commercially available Algerian frying edible oils. International Food Research Journal 24 (1), 60, 2017.

26. EUROPEAN UNION. Passenger Cars and Light Duty Vehicles. Accessed from https://d2ou7ivda5raf2. cloudfront.net/sites/default/files/inline-files/2017\%20 2018\%20 Worldwide\%20Emissions\%20Standards\%20 Passenger\%20Cars\%20 Light $\% 20$ Duty.pdf on $20^{\text {th }}$ of February, 2018.

27. CERVIGNI R., DVORAK I., ROGERS I.J.A. Assessing Low-Carbon Development in Nigeria: An Analysis of Four Sectors. Accessed from https://books.google.com.ng/book s?id=WooC72dBY1IC\&pg=PA363\&lpg=PA363\&dq on $9^{\text {th }}$ March, 2018.

28. YASAR A., RIZWAN H., AMTUL B., FIDOUS K., MARYAM K. A Comparison of Engine Emissions from Heavy, Medium, and Light Vehicles for CNG, Diesel, and Gasoline Fuels. Pol. J. Environ. Stud. 22 (4), 1277, 2013.

29. INTERNATIONAL COUNCIL ON CLEAN TRANSPORTATION. EU $\mathrm{CO}_{2}$ Emission Standards for Passenger Cars and light-commercial vehicles. Policy Update on Environment 2195, 2014.

30. GOZUBUYUK A.A., DAG H., KACAR A., KARAKURT Y., ARICA V. Epidemiology, pathophysiology, clinical evaluation, and treatment of carbon monoxide poisoning in child, infant, and fetus. Northern Clinics of Istanbul, 4 (1), 100, 2017.

31. AKYOL S., ERDOGAN S., IDIZ N., CELIK S., KAYA M., UCAR F., DANE S., AKYOL O. The role of reactive oxygen species and oxidative stress in carbon monoxide toxicity: An in-depth analysis. Redox Rep. 19, 180, 2014.

32. EPA. National Ambient Air Quality Standards table. Accessed from https://www.epa.gov/criteria-air-pollutants/ naaqs-table. Last updated December, 20, 2016.

33. REŞITOĞLU İ.A., ALTINIŞIK K., KESKIN A. The pollutant emissions from diesel-engine vehicles and exhaust after treatment systems. A. Clean Techn Environ Policy 17, 15, 2015.

34. LI R., WANG Z., XU G. Study on Carbonyl Emissions of Diesel Engine Fueled with Biodiesel. International Journal of Chemical Engineering, vol. 2017, Article ID 1409495, 12, 2017.

35. ABDULlAH M.F.E., ZHING S.S., BUGIK C.B. Biodiesel unsaturation degree effects on diesel engine NOx emissions and cotton wick flame temperature. MATEC Web of Conferences (90), 01041. DOI: 10.1051/ matecconf/201 79001041. 2017. 
